\title{
New Insights into Early Iron Age Connections between Sardinia and Etruria: Archaeometric Analyses of Ceramics from Tavolara
}

Silvia Amicone ${ }^{1,2}$, Kyle P. Freund ${ }^{3}$, Paola Mancini ${ }^{4}$, Rubens D’Oriano ${ }^{5}$, C. Berthold ${ }^{1}$

${ }^{1}$ Competence Center Archaeometry-Baden-Württemberg, University of Tübingen, Wilhelmstrasse 56, 72074 Tübingen, Germany

${ }^{2}$ Institute of Archaeology, University College London, 31-34 Gordon Square, London WC1H OPY, UK

${ }^{3}$ Department of Anthropology, Indian River State College, 3209 Virginia Avenue, Fort Pierce, FL 34981, USA

${ }^{4}$ Independent Researcher, Italy

${ }^{5}$ Soprintendeza Archeologia, Belle Arti e Paesaggio per le Province di Sassari e Nuoro, Via Capo Testa 28, 07026 Olbia (SS), Italy

"Corresponding author: Silvia Amicone

E-mail: silvia.amicone@uni-tuebingen.de

Phone: 49-(0)7071/2976801 


\section{Abstract}

The island of Tavolara off the coast of northeastern Sardinia, Italy was intermittently occupied from Neolithic to modern times, and recent excavations at the site of Spalmatore di Terra have revealed the presence of Villanovan ceramics on the island dating to the $9^{\text {th }}$ century BC (according to the traditional chronology). Contacts between Etruria and Sardinia during the early Iron Age are well documented by the recovery of Nuragic vessels and metal objects in Etrurian burial contexts, but the presence of Villanovan artefacts in Sardinia is comparably rare. Indeed, discoveries from Spalamatore di Terra represent the first evidence of Villanovan ceramics in Sardinia, likely originating from Tyrrhenian Etruria.

To study the provenance of the ceramics found at Spalamatore di Terra, a representative sample of these materials was chosen to be studied through a combination of petrographic and geochemical characterisation. A particular emphasis was placed on the Villanovan materials that were most abundant, but a selection of Nuragic shapes was also included. The results of these analyses are significant in that they reveal a surprisingly diverse range of ceramic fabrics that can be linked to Etruria, thus providing insight into Tavolara's place within a broader transmarine network of interaction.

Keywords: Sardinia; Etruria; Tavolara Island; Villanovan ceramics; Petrography; X-Ray Fluorescence (XRF) Spectrometry

\section{Introduction}

The period between the $12^{\text {th }}$ and $10^{\text {th }}$ centuries BC saw substantial changes occurring around the Tyrrhenian Sea. In central Italy, a reorganisation of residential settlements set the foundation for the emergence of Etruscan cities (Protovillanovan and Villanovan phases), while on Sardinia, Nuragic communities reached their peak in terms of monumental 
architecture and long-distance trade (Lo Schiavo et al., 1985). Although connections between these two regions are well documented in this era (e.g. Camporeale, 2013; Cohen, 2018; Cygielman, et al., 2015; Delpino, 2002; Iaia, 2017; Kristiansen, 1993; Lo Schiavo, 2005; Lo Schiavo and Milletti, 2014; Lo Schiavo et al., 2013; Milletti, 2012; Morandi, forthcoming; Zucca, 2012), the commercial and cultural exchanges are only known from metal and ceramic objects associated with elites (Milletti, 2012 and literature therein). Moreover, there is a consensus among scholars that Nuragic objects in Etruria represent the presence of Sardinian elites on the mainland, whose relations with upper-class Villanovans also included the exchange of knowledge, kin relations, and other perishable goods (Milletti, 2012, 206, 229230). For example, in Etruria a diverse range of Sardinian material culture is common and includes figured bronzes, daggers, wine jugs, swords, and cauldrons. In contrast, the presence of Villanovan artefacts in Sardinia is comparably rare and less diversified, taking form as axes, fibulae, swords, and razors (e.g. Lo Schiavo, 1978; Salis and Minoja, 2015). The archaeological evidence so far uncovered indicates that the privileged area of connections between Villanovans and insular civilizations would be Northern Etruria (Milletti, 2012).

New work at the archaeological site of Spalmatore di Terra on the Sardinian island of Tavolara (Fig. 1) is shedding further light on cultural connections between Etruria and the surrounding areas revealing what may be the first evidence of Villanovan ceramics outside of the Italian peninsula and suggesting possible visitation to Sardinia by those from the mainland (Di Gennaro, 2019) during the $9^{\text {th }}$ century BC (according to the traditional chronology, for the debate on Italian Iron Age chronology see Bartoloni and Delfino, 2005). Tavolara is located in the municipality of Olbia (SS) and is currently part of a protected marine sanctuary (Area Marina Protetta Tavolara - Punta Coda Cavallo). By applying ceramic petrography and portable X-ray fluorescence (pXRF) spectrometry to a representative sample of ceramics from the site, this study aims to elucidate the provenance of these materials, and to assess whether there is 
evidence that vessels displaying Villanovan typological characteristics were created at production centres in mainland Italy.

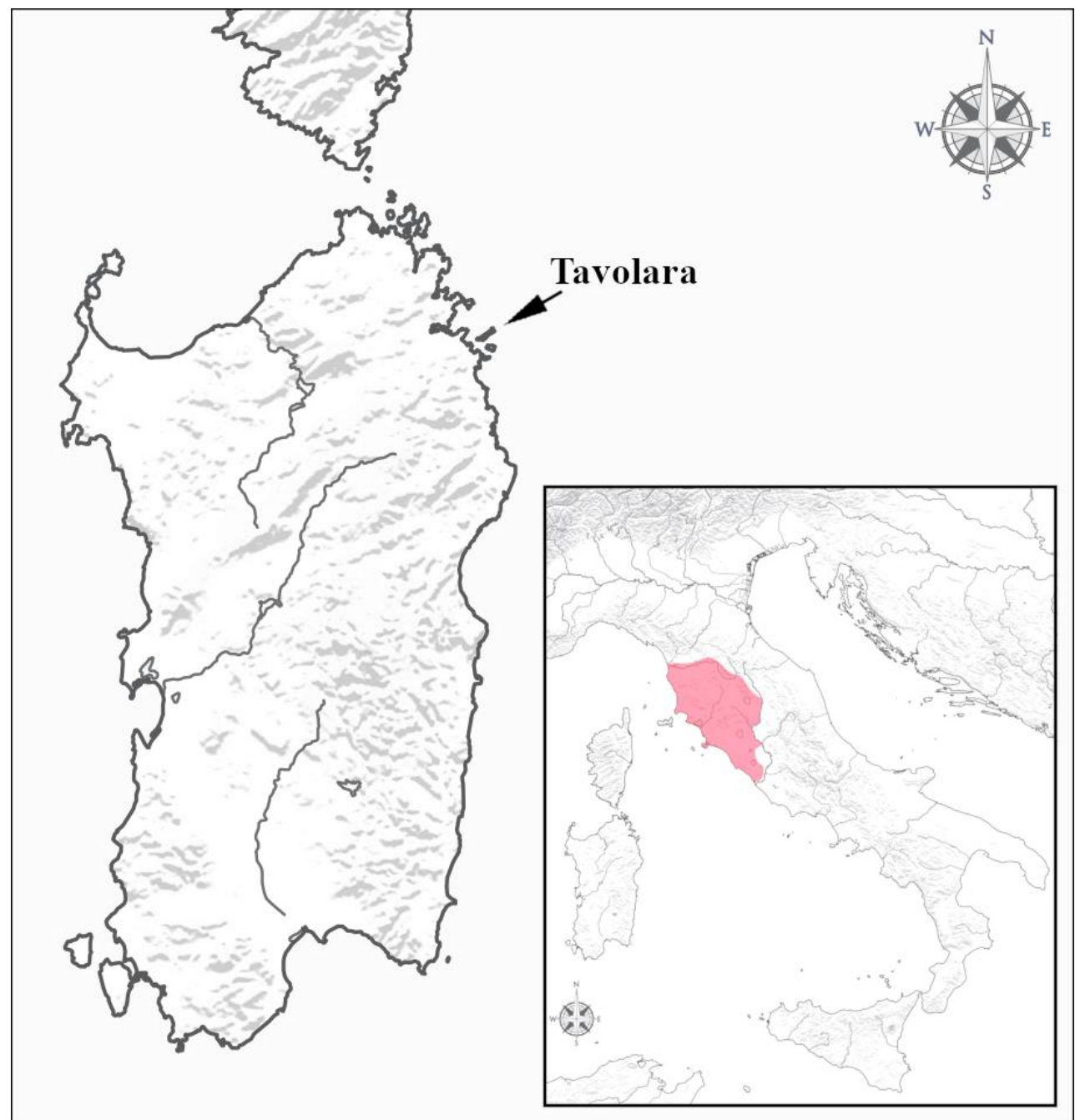

Fig. 1. Map of Sardinia with the location of Tavolara (left); map of Italy with Etruria (shaded on right). Courtesy of L. Heinze.

\subsection{Tavolara and the archaeological excavations at Spalmatore di Terra}

The island of Tavolara consists of a rectangular limestone massif about $6 \mathrm{~km}$ long and $1 \mathrm{~km}$ wide (Fig. 2). The island reaches a maximum altitude of 565 meters a.s.l. and rests on a granite bedrock that is visible in certain areas. Tavolara is flanked by two easily accessible capes at each end; the cape on the west side of the island (Spalmatore di Terra) is facing Loiri Porto San Paolo. 
Excavations at Spalmatore di Terra were carried out by Paola Mancini in 2011 and 2013, financed by the Area Marina Protetta Tavolara under the scientific direction of Dr. Rubens D'Oriano of the Soprintendenza Archeologia, Belle Arti e Paesaggio per le Province di Sassari e Nuoro. The investigation concentrated on a roughly 225 square meter area where a high concentration of artefacts were identified on the surface. A series of trenches were then excavated to better understand the nature of the deposits and their chronology. The combination of surface survey and targeted excavation revealed evidence of an Iron Age frequentation, replete with a large quantity of Villanovan pottery found in association with pits and possible hearths.
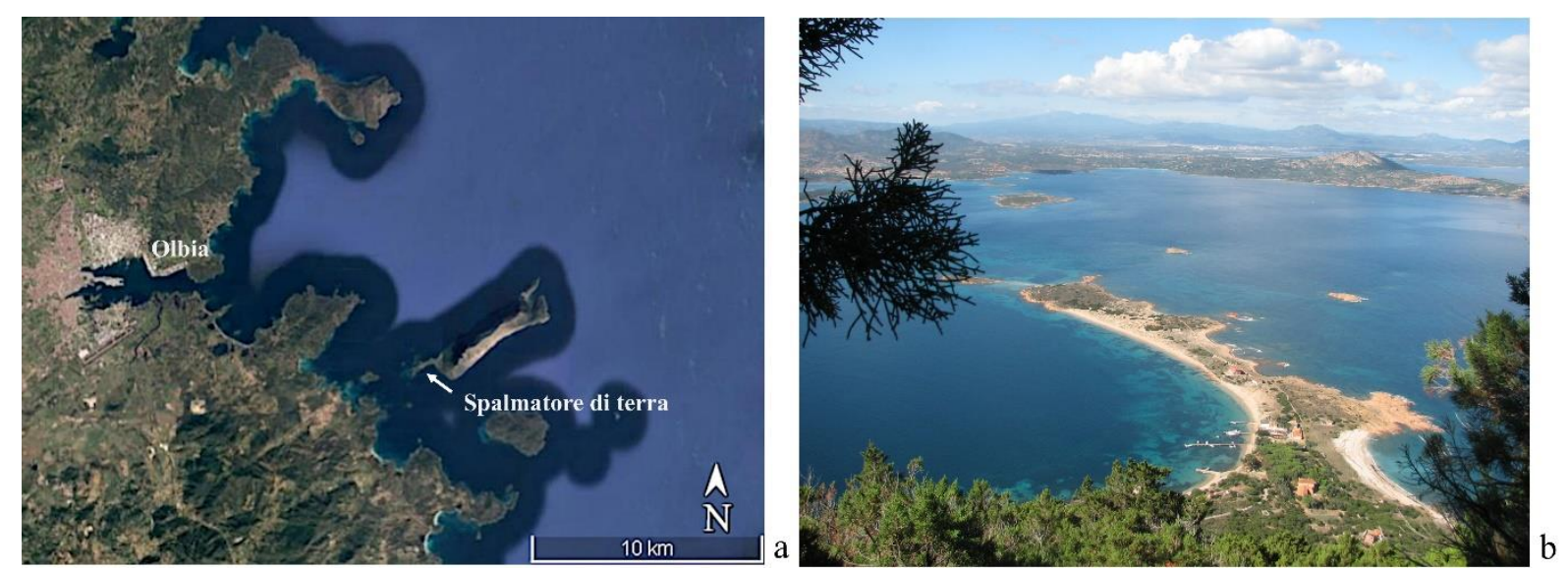

Fig. 2. Map displaying the location of Spalmatore di Terra on the island of Tavolara, Sardinia (left); photograph overlooking Tavolara, facing west (right).

The ceramic assemblage was primarily composed of olle with flared rims of reddish colour (Fig. 3), generally decorated with smooth plastic cords and digital impressions that resembled containers found at the coastal sites of middle-Tyrrhenian Italy (see Alessandri et al., 2019; Aranguren et al., 2014; Pacciarelli, 2000 and literature therein; Rossi, 2017). These vessels are also known as olle d'impasto rossiccio and are traditionally connected to briquetage workshops for salt production (Pacciarelli, 2000, 176). However, the connection to salt production is not univocal, and new evidence from Tavolara sheds new light on the diverse functions of these vessels. 
In addition, fragments with typical Villanovan geometric decorations and no clear form were discovered, with the exception of a single biconical vessel (di Gennaro, 2019; di Gennaro et al., forthcoming) and a smaller number of Nuragic sherds were also identified.

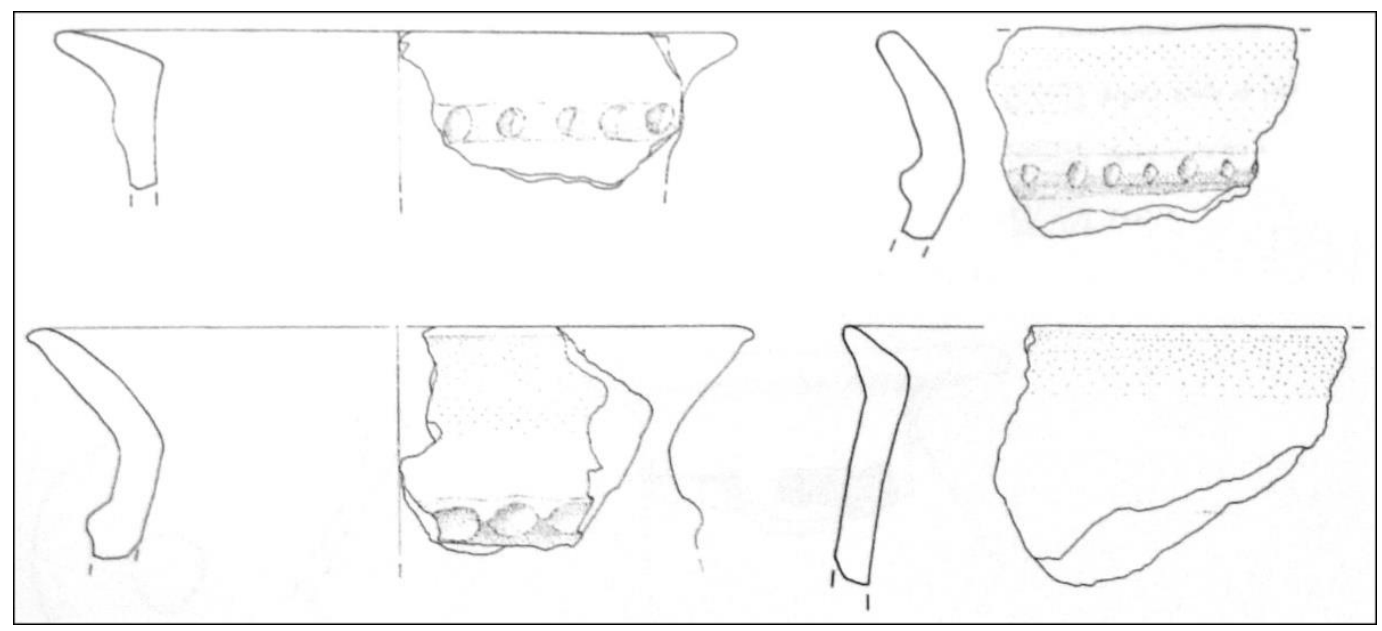

Fig. 3. Olle cordonate pottery from various sites in Etruria (after Pacciarelli 2000).

\section{Materials and Methods}

\section{1}

A sample of 43 ceramic artefacts representing all the macroscopic fabrics and shapes recognised in the Splamatore di Terra assemblage was selected for analysis (Table 1). These include olle with flared rims and decorated with smooth plastic cords and digital impressions, wall fragments with geometric designs, and a smaller number of Nuragic fragments. These 43 samples were analysed via ceramic thin section petrography. On the basis of these results, 35 fragments were analysed via pXRF spectrometry. The employment of an integrated programme of analyses for defining compositional diversities in pottery assemblages provides highly detailed results (Day et al., 1999), and in this context the combination of chemical and petrographic data allows us to determine whether different chemical groups identified through statistical analysis correspond to unique provenances or technological traditions, or to a combination of both. 


\subsection{Petrography}

Petrographic analysis of archaeological ceramics consists of the description, classification, and interpretation of ceramic pastes or fabrics, adopting techniques derived from those used in geology and soil micromorphology to describe rocks (Quinn, 2013; Whitbread, 1995). Petrography allows researchers to discern the different technological aspects of ceramic production and helps to define raw material sources employed in pottery manufacture, thus providing important information about artefact provenance.

For this study, a collection of 43 samples were thin-sectioned and then analysed with a Leica DM 2500P at the Institute of Archaeology of the University College London (UCL) and at the Competence Center for Archaeometry-Baden-Wuerttemberg (CCA-BW, University of Tübingen).

\subsection{Elemental Characterisation via pXRF}

The elemental characterisation of ceramic assemblages has a long history in archaeological research dating back to the 1950s (e.g. Sayre and Dodson, 1957; see Orton and Hughes, 2013, 160-182 for a review). When combined with petrographic analysis, it is a particularly powerful tool with the capacity to reveal distinct pottery production practices.

Over the past 20 years, archaeologists have used a range of archaeometric techniques to characterize ceramic assemblages. The most common include neutron activation analysis (NAA; e.g. Eckert et al., 2015), proton induced X-ray emission (PIXE; e.g. Kieft et al., 2002), and X-ray fluorescence (XRF) spectrometry (e.g. Hunt and Speakman, 2015). For this study, a Thermo Niton XL3t portable XRF instrument was used, in turn taking three separate measurements on each sherd and averaging the results. Both the inner and outer surfaces of each sample were analysed as well as their cross sections to account for heterogeneity. Each run lasted six minutes with no vacuum, and the results were calibrated using a ceramic 
calibration developed at Goethe-Universität in Frankfurt am Main (see Helfert et al., 2011; Amicone et al., 2020). Results for major elements were normalized to $100 \%$ in their oxide form, calculated by stoichiometry, while the trace elements were quantified in ppm.

\section{Results}

On the basis of the compositional and textural characteristics of the samples, it was possible to classify the specimens from Spalmatore di Terra into eight distinct fabrics (Figs. 4 and 5; for full petrographic description see Table 2). A selection of samples representative of these eight fabrics was analysed via pXRF, and when compared with the petrographic data a robust interpretation of pottery production at Spalmatore di Terra could be elucidated. Table 3 displays the results from the $\mathrm{pXRF}$ analyses. Based on an exploratory analysis of the data, we determined that hierarchical cluster analysis utilizing a $\log 10$ transformation of the measurements of $\mathrm{Cr}, \mathrm{Ni}, \mathrm{Zn}, \mathrm{Rb}, \mathrm{Sr}, \mathrm{Y}, \mathrm{Zr}$, and $\mathrm{Ba}$ was most useful in identifying distinct compositional groups (Fig. 6). The patterns observed via hierarchical cluster analysis were further supported via principal component analysis (PCA). The highest cumulative variance for principal components 1 and 2 was achieved using the elements $\mathrm{Cr}, \mathrm{Zn}, \mathrm{Rb}, \mathrm{Sr}, \mathrm{Y}, \mathrm{Zr}$, and $\mathrm{Pb}$ (Fig. 7).

\section{$\underline{\text { A - Granitic fabric (Fig. 4, a-b) }}$}

This paste is characterised by fragments of intrusive magmatic rocks added as temper.

These are composed of quartz and feldspars as well as lower quantities of biotite and amphiboles. The composition is indicative of granite.

$\underline{\text { B - Effusive fabric (Fig. 4, b-f) }}$

Samples assigned to this coarse fabric form a heterogeneous group marked by the presence of pyroxenes, feldspars (sanidine and plagioclase), volcanic rock fragments used as 
tempering materials. Other common inclusions are fragments of volcanic glass and quartz more rarely amphibole and biotite. This fabric can be divided into two main sub-fabrics (B1 and B2). Both contain large pyroxene inclusions $(0.8 \mathrm{~mm})$ that are more abundant in B1 than in B2. From a geochemical point of view, specimens of both sub-fabrics B1 and B2 are characterised by relatively high concentrations of $\mathrm{Sr}$ and $\mathrm{Zr}$. The strong bimodality in the grain size distribution observed in this group suggests that the clay has been well cleaned before the addition of the tempers.

Samples Tav 21 and Tav 22 deserve separate attention in that they have a different texture (less abundant and smaller inclusions) when compared to the other samples assigned to fabric B and are marked by a less frequent occurrence of pyroxenes. These specimens also show lower concentrations of $\mathrm{Rb}$ and $\mathrm{Sr}$, and therefore do not group together with the other samples attributed to fabric B in the dendrogram obtained through hierarchical analysis (Fig. 6). However, the strong compositional similarity (presence of pyronenes and volcanic rocks) suggests that these samples are related to fabric B. The textural differences may be explained in terms of different cleaning and tempering techniques. Put another way, the potters could have cleaned more or less intensely the base clay and could have added tempering agents marked by different sorting and grain sizes. 

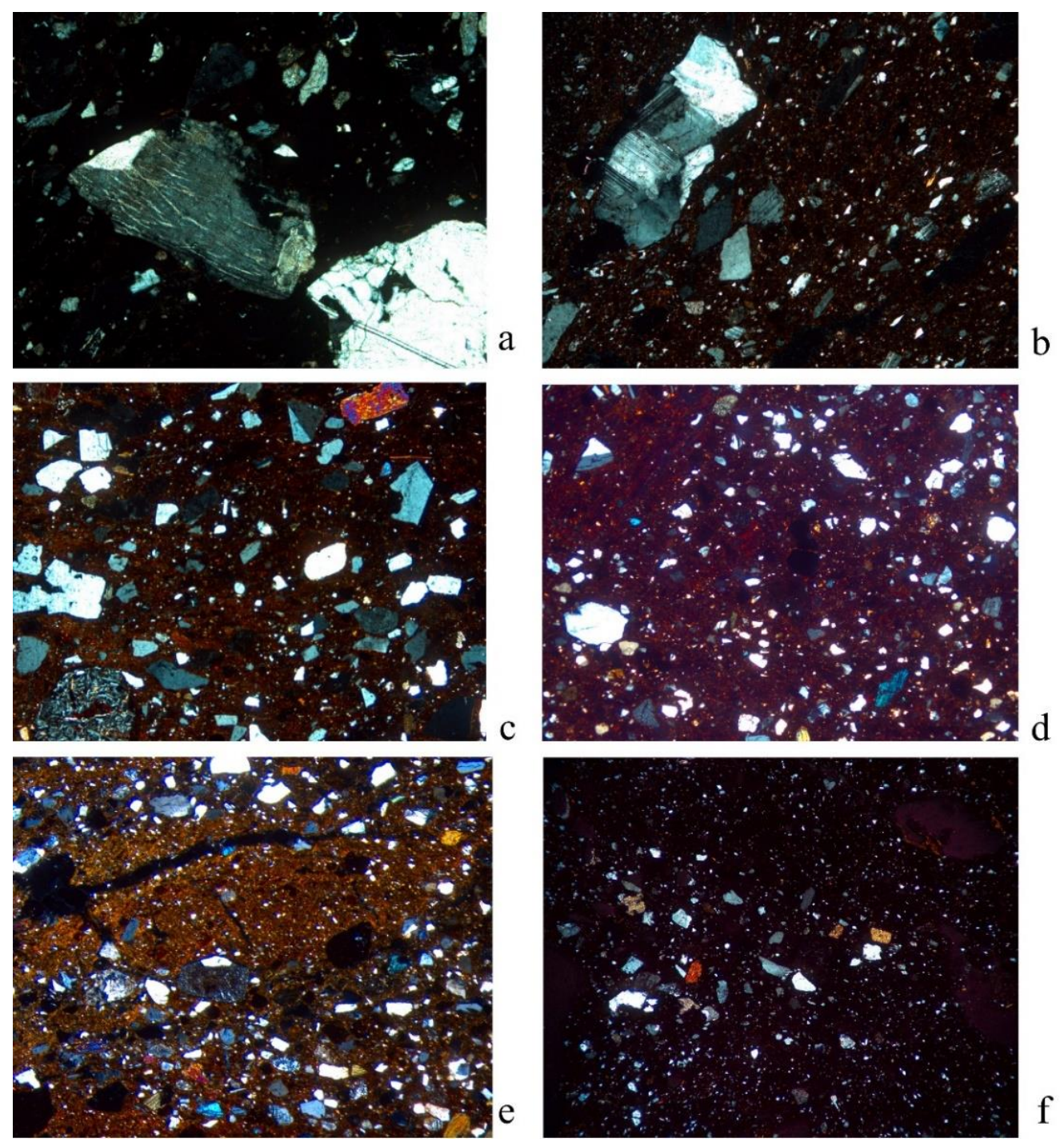

Fig. 4. Thin section photomicrographs of selected ceramic samples from Tavolara: a) Sample Tav 6 (A: granitic fabric); b) Sample Tav 5 (A: granitic fabric); c) Sample Tav 1 (B1: effusive fabric, coarse); d) Sample Tav 23 (B2: effusive fabric, fine); e) Sample Tav 21 (B: effusive fabric); f) Tav 22 (B: effusive fabric). Pictures taken under XP; field of view: $3 \mathrm{~mm}$ $\mathrm{a}-\mathrm{b} ; 6 \mathrm{~mm} \mathrm{c}-\mathrm{f}$.

\section{$\underline{\mathrm{C}-\text { Effusive and metamorphic fabric (Fig. } 5 \text { a-b) }}$}

Samples assigned to this fabric form a heterogeneous group marked by the presence of clay pellets, iron rich inclusions, and fragments of volcanic rocks composed of feldspars. Other common mineral inclusions are quartz, feldspars, chert, and fragments of sedimentary and metamorphic rocks. Pyroxenes are also present, but rarer.

The fabric could be divided into two sub-fabrics (C1-C2). C1 includes ollae and it is coarser; the bimodal grain-size distribution that characterises this sub-fabric suggests 
tempering. C2 comprises samples with thinner walls and finer textures that are possibly derived from biconical vessels. These different tempering strategies could also explain why these two sub-fabrics do not group together from a geochemical point of view. Sample Tav 4 is particularly unique in terms of its chemical composition and is marked by relatively low levels of $\mathrm{Cr}, \mathrm{Zn}, \mathrm{Rb}, \mathrm{Sr}$, and $\mathrm{Zr}$. This is a very fine-grained sample, so even if petrographically it seems to be related to fabric $\mathrm{C}$, we can't exclude it as a loner.

$\underline{\text { D - Weathered minerals fabric (Fig. 5, d) }}$

This fabric is only represented by three samples and is marked by weathered minerals and rocks as well as a minor quantity of volcanic rock fragments. Other common mineral inclusions are quartz, feldspars, more rarely chert, pyroxene, and possible fragments of sedimentary and metamorphic rocks. The strong bimodal distribution that characterises these samples suggest tempering.

\section{$\underline{\text { E - Flint fabric (Fig. 5, e) }}$}

This fabric is marked by the addition of flint as tempering material. Other inclusions are quartz, feldspars, chert, and rare fragments of metamorphic rocks.

\section{Group F - Grog fabric - Tav 38 (Fig. 5, f)}

This fabric is only represented by one sample that is marked by the addition of grog as tempering material. Other inclusions are quartz, feldspars, chert, and rare fragments of metamorphic and sedimentary rocks. 

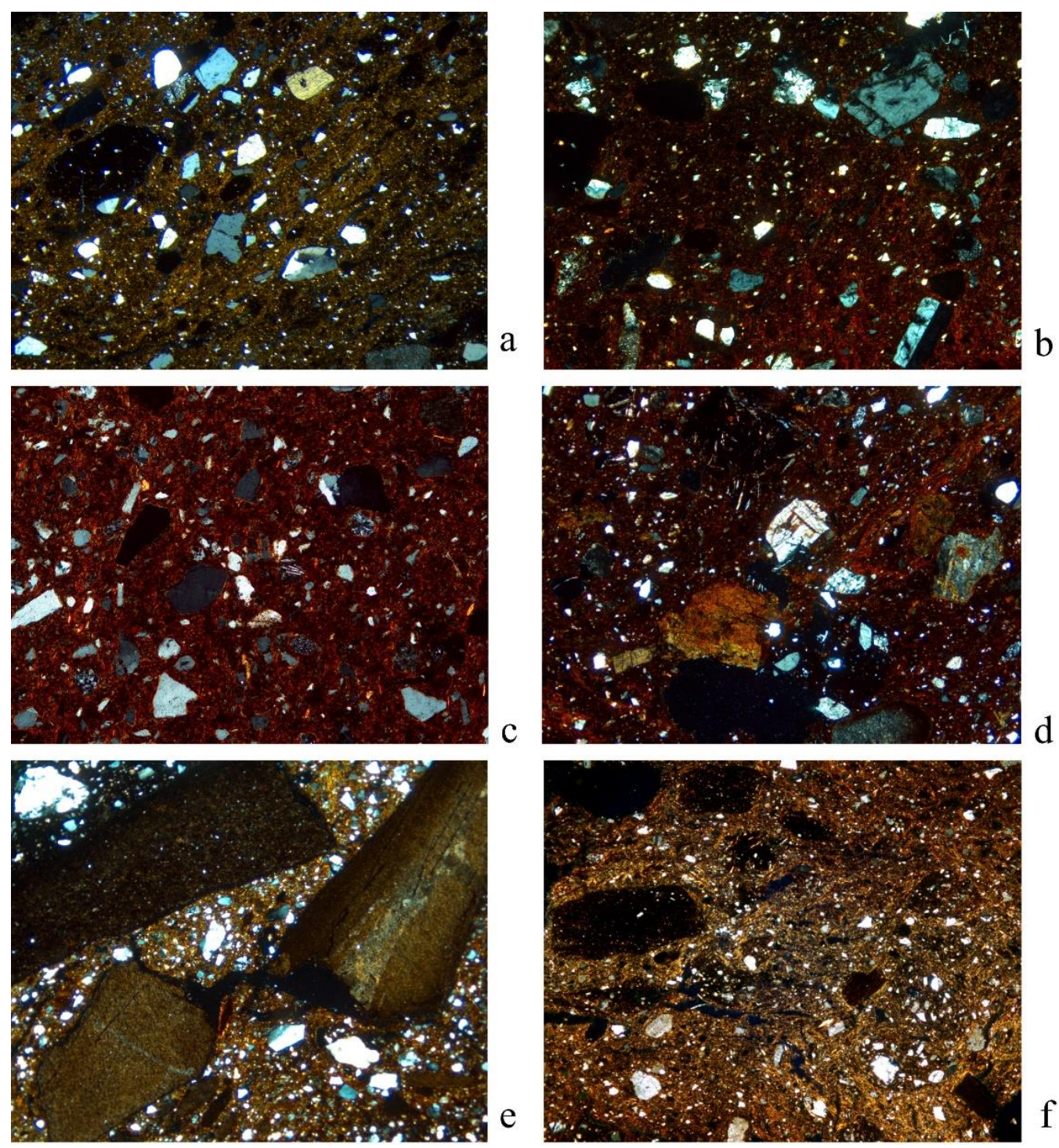

Fig. 5. Thin section photomicrographs of selected ceramic samples from Tavolara: a) Sample Tav 3 (C1: effusive and metamorphic fabric, coarse); b) Sample Tav 20 (C1: effusive and metamorphic fabric, coarse); c) Sample Tav 12 (C2: effusive and metamorphic fabric, fine); d) Sample Tav 9 (D: weathered minerals fabric); e) Sample Tav 16 (E: flint fabric); f) Sample Tav 38 (F: grog fabric). Pictures taken under XP; field of view: 6mm a, d-f; $3 \mathrm{~mm} \mathrm{~b} ; 1.5 \mathrm{c}$. 


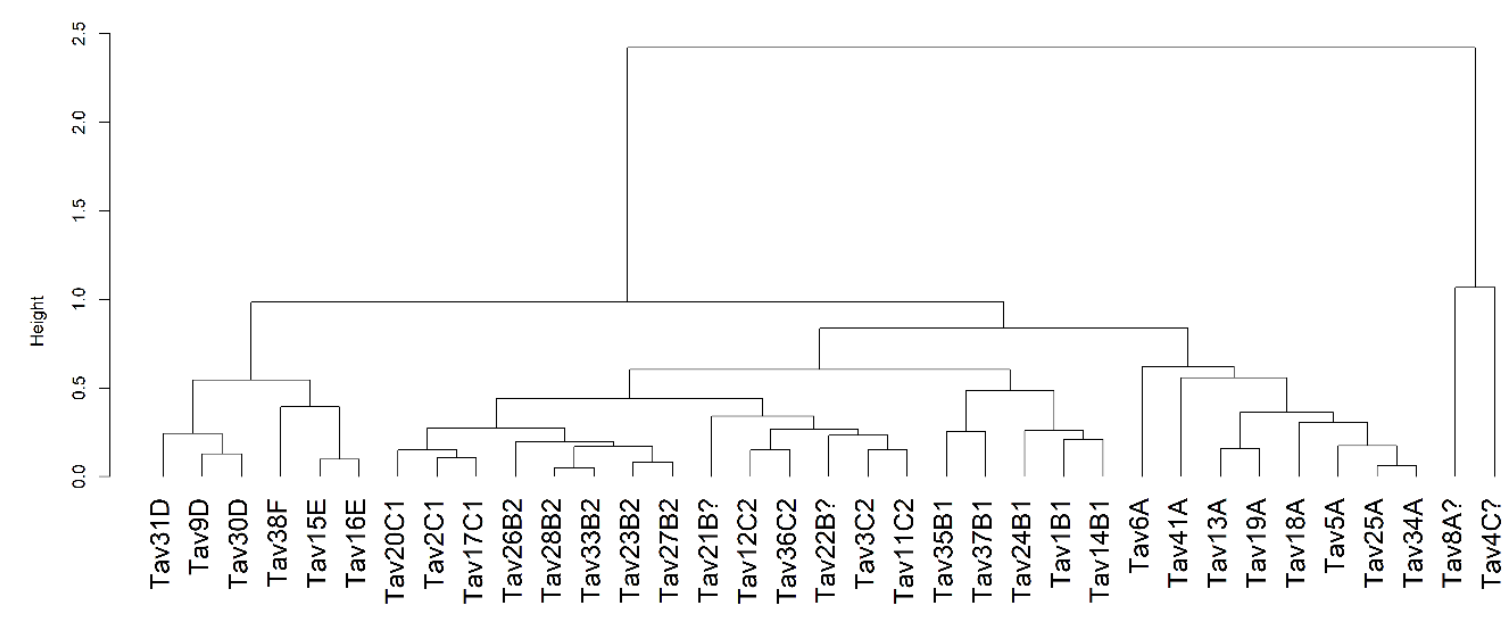

Fig. 6. Cluster dendrogram derived from the geochemical characterisation of Spalmatore di Terra samples (average linkage method).
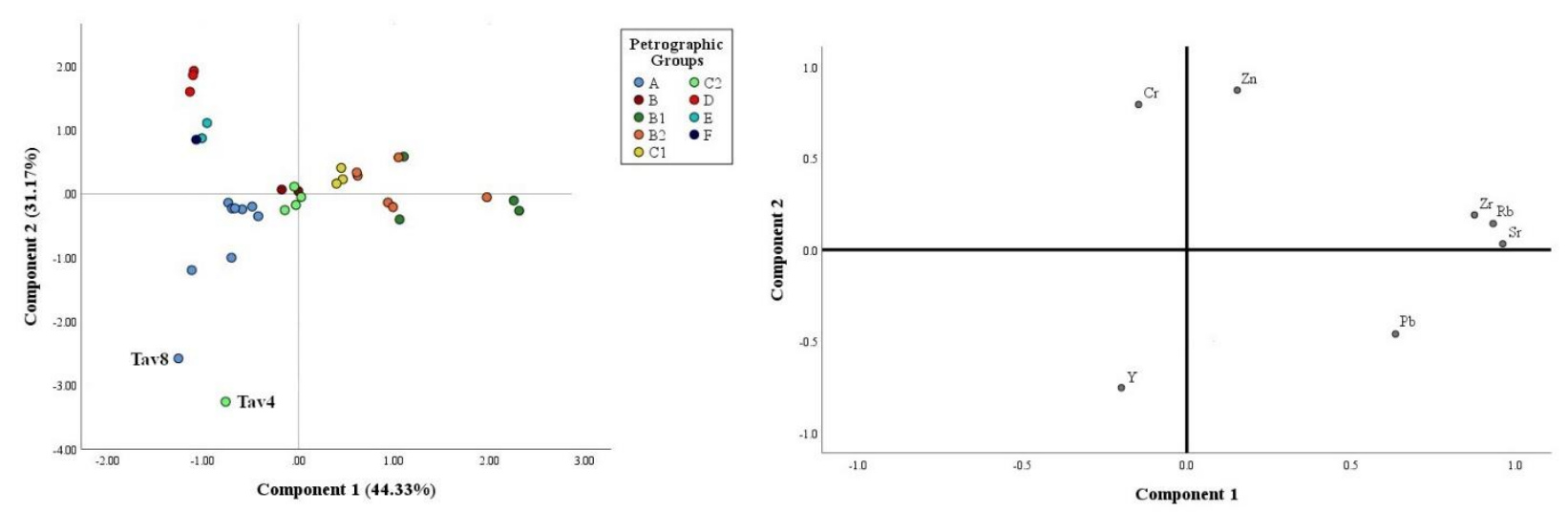

Fig. 7. Principal component analysis (PCA) results derived from the geochemical characterisation of Spalmatore di Terra samples (left); loading plots resulting from the PCA analysis (right).

\section{Discussion}

Archaeometric analyses of the selected ceramic sherds from Tavolara have allowed us to recognise different ceramic fabrics that reflect a diverse geology. The results suggest that the assemblage originates from a variety of production centres. This scenario is worthy of discussion in relation to the geology of Sardinia and the Tyrrhenian coast and as well as the published archaeometric data from these regions.

The composition of fabric A connects to the geology of Gallura, which is dominated by the presence igneous intrusive rocks (granite). However, none of the samples falling into this group are marked by typological traits that would connect them to Villanovan traditions. 
Suitable clay for pottery making is not easily found on the island of Tavolara; therefore, this group could represent a regional production rather than a local one.

The mineralogical characterisation of the samples that were stylistically interpreted as Villanovan ceramics (di Gennaro, 2019) supports a north Tyrrhenian origin, in particular the area of Tuscany and North Latium (Fig. 8, a). These samples include the cordoned ollae and the walls decorated with geometric designs. Previous research on Villanovan ceramics has primarily focused on decoration and typology (e.g. De Angelis, 2001; Guidi, 1980, Toms, 1996), whereas archaeometric studies are comparably limited (e.g. Interdonato, 2013; Morandi et al., 2018). This study therefore makes an initial, yet important contribution to our understanding of the multifarious ceramic production traditions of the Villanovan world and their connections to Sardinia.

The geology of Tuscany (Fig. 8, b) is dominated by different types of metamorphic and sedimentary formations created in different eras (Carmignani and Lazzarotto, 2004). Pliocene and Quaternary intrusive magmatic and effusive pyroclastic formations also occur more rarely in this region. Intrusive magmatic formations are found, for example, on the islands of Elba and Giglio as well as the Montecristo islands, and outcrops of volcanic rocks are located on Capraia island, in Mount Amiata, in the Area del Tufo, and in the vicinity of S. Vicenzo and Rocca Strada (Fig. 8, b).

The area of northern Latium is marked by Quaternary effusive formations (Fig. 8, b). The effusive activity started in the Pleistocene and includes the ignimbrites and acidic lava domes of the "massifs" of Tolfa and Allumiere. Farther north, the rise of the basic magma determines the formation of Vulsini volcanic systems marked by ignimbrite plateaus and calderas (Force, 2015; Alberti et al., 1970, 41). Marine, lacustrine, and fluvial deposits are also common in the region. These mark the existence of different petrologic provinces derived from 
multiple magmatic-arc and orogenic sources (Garzanti et al, 2002,6) and are the materials most likely used for pottery production.
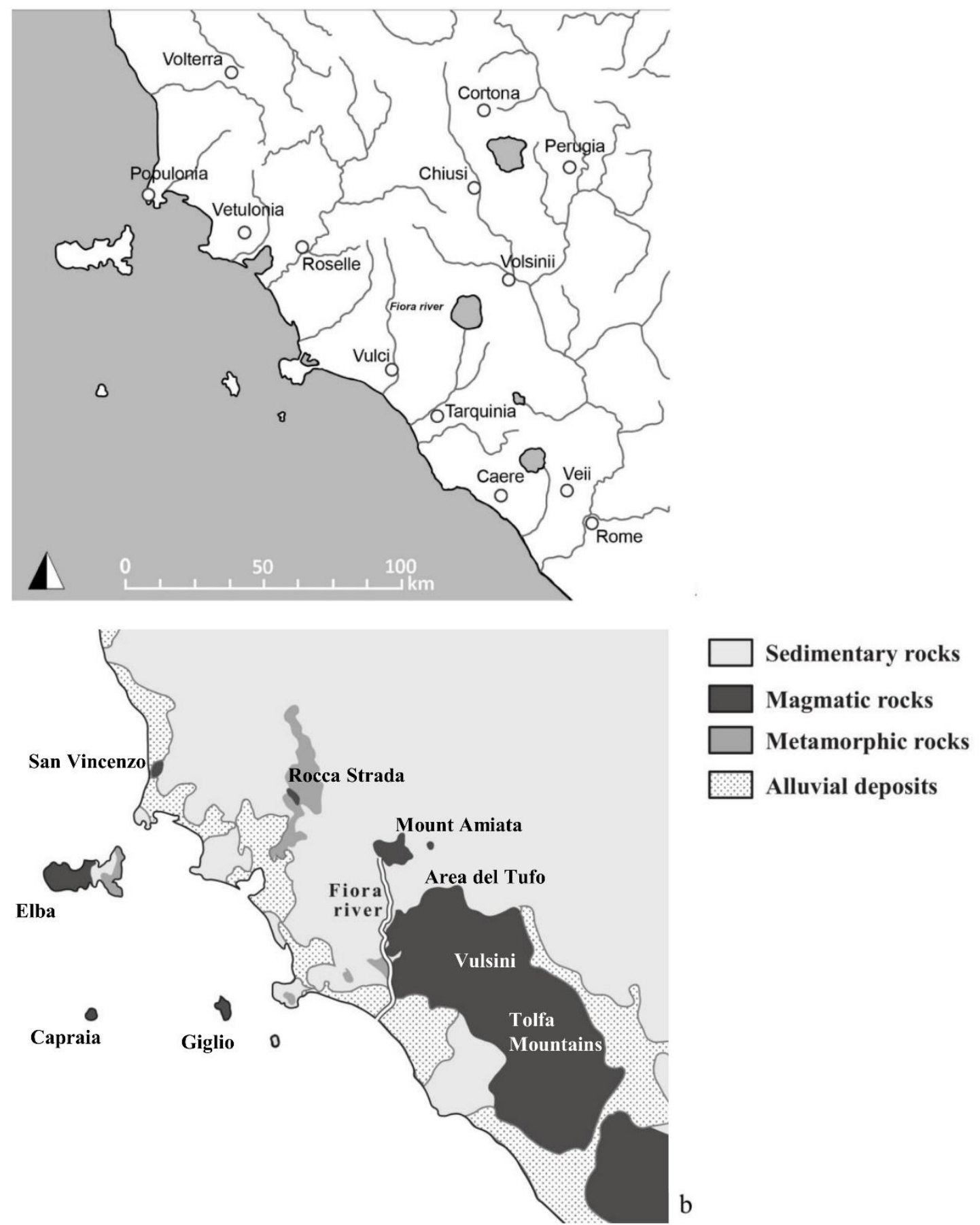

Fig. 8. a) Map of Etruria displaying the locations of the main Villanovan settlements (top; courtesy of L. Morandi); b) Map of Etruria displaying the major geo-lithological formations (bottom). The shore lines in both maps reflect the bathymetry of the $1^{\text {st }}$ millennium BC (courtesy of L. Heinze). 
Compositional analysis of ceramics of the Villanovan period are limited (e.g. Aranguren et al., 2014; Interdonato, 2013; Ottomano, 2006; Trojsi, 2012). However, studies of the preceding Neolithic, Copper Age, and Bronze Age periods (Martini et al., 1996; De Marco, 2017; Forte and Medeghini, 2017; Levi et al., 2019) can provide insights into the pottery from this area in that these wares are typically composed of metamorphic or volcanic raw materials. The composition of fabrics B and C suggest an origin in the area between south Tuscany and North Latium, more specifically for fabric $\mathrm{C}$ the middle valley of the Fiora River and its tributaries in the area of Pitigliano and the hills close to the coastline in the area of Capalbio. The area is marked by volcanic rocks to the east of the Fiora, while to the west there are sedimentary and volcanic rocks. The Fiora River flows along the limits between the volcanic, metamorphic, and sedimentary rocks. Bronze Age ceramics (see Martini et al., 1996; Levi et $a l ., 2019)$ from this area are marked by effusive fabrics (e.g. Sorgenti della Nova in the province of Viterbo or Garavicchio, Mulino Rossi, Poggiati Vallelunga, Poggio Buco-Le Sparne; in the province of Grosseto) or effusive and metamorphic fabrics (e.g. Scarceta in the province of Grosseto, and Grotta Nuova in the province of Viterbo).

The effusive and metamorphic fabric SQ as defined by Martini et al. $(1996,304)$ looks similar to the fabric C of this study (Fig. 9), and it has been found in association with sites of the Fiora Valley. On the other hand, the effusive fabric SA as defined by Martini et al. (1996, 303) is marked by the associated sanidine-augite that is a good parallel for our fabric B (Fig. 9). This type of paste can be also be found at archaeological sites of the Fiora Valley (Martini et al., 1996). Nevertheless, similar fabrics are also present in other areas of North and Central Latium (e.g. Muntoni and Pallecchi, 2002; Forte and Medeghini, 2017 and literature therein; Borges et al., 2018), and without more detailed geochemical investigations it is not possible to make further inferences about the provenance of this ceramic paste. It is also important to note that the samples assigned to fabrics B and C form heterogenous groups that could reflect several 
production centres marked by a similar geology, but different clay processing and tempering traditions.
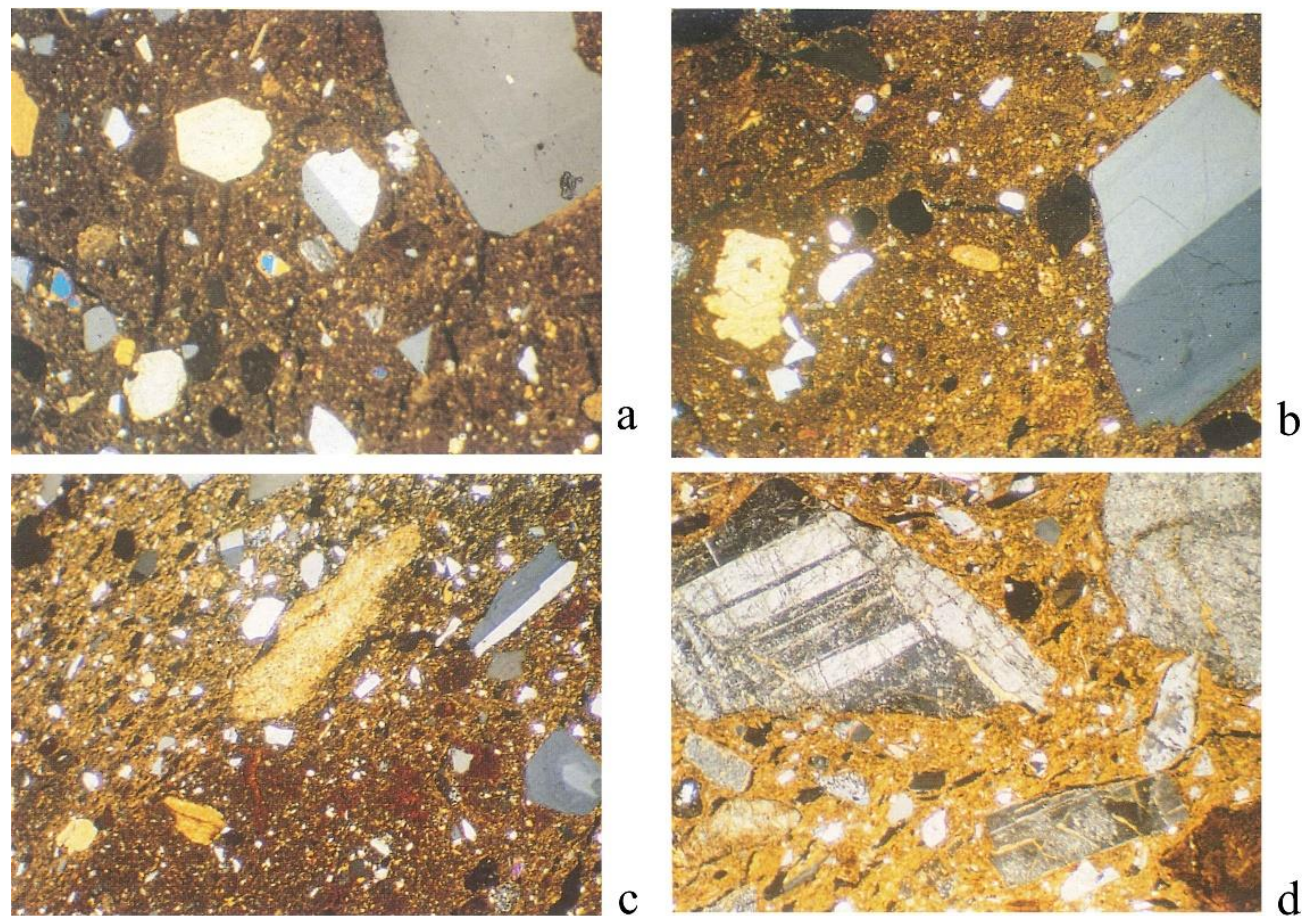

Fig. 9. Thin section photomicrographs of fabrics mentioned in the study of Martini et al. 1996: a) Fabric SA (effusive fabric, Grotta Nuova- Middle Bronze Age, p. 346 n.25); b) Fabric SA (effusive fabric, Poggio Buco/Le Sparne- Final Bronze Age, p. 349 n.48); c) Fabric SQ (effusive and metamorphic fabric, Sorgenti della Nova/La Roccaccia- Final Bronze Age, p. 353 n.72); d) Fabric PID (plagioclase and diallage fabric, Grotta San Giuseppe-Eneolithic, p. 435 n. 19). After Martini et al. 1996.

Finally, the absence of effusive components in fabrics $\mathrm{E}$ and $\mathrm{F}$ and the presence of metamorphic rocks could suggest a provenance from northern Tuscany. The occurrence of flint in fabric E further supports this hypothesis. Limestone formations rich in flint can be found near Pisa (Franzini and Lezzerini, 1998). On the other hand, the composition of fabric D shows a good parallel with Bronze Age materials from Torre Mozza (De Marco 2017, 73-75), more precisely with fabric PD that is considered a local production employing tempers from local ophiolitic formations. A similar fabric has been also recognised in the Eneolithic site of Grotta San Giuseppe (Fig. 9) on the island of Elba (Martini et al. 1996, 153-155). This is also considered a local production connected to the metamorphic and ophiolitic outcrops that define 
the local geology. In general, this fabric seems to be typical for many protohistoric sites of the Piombino district (Martini et al., 1996).

In the absence of a more systematic technological and archaeometric study of ceramics and clay sources from the area of the development of the Villanovan complex, the hypotheses regarding the provenance of the sherds from Spalmatore di Terra cannot be definitively confirmed. However, there is a good evidence that samples assigned to fabrics B to F could come from different areas of Etruria (Table 1). Any such investigation in the future should include both petrographic and geochemical analyses, the latter not only to define the bulk chemistry of the ceramic and clay samples, but also the detailed composition of pyroxene inclusions. Pyroxenes seem to be one of the most common minerals found both in the Spalmatore di Terra sherds and in the different petrologic provinces that mark the river and beach sands along the Tyrrhenian Sea (Garzanti et al., 2002, 6). Therefore, from a geochemical perspective we can infer more detailed information about the provenance of the sediments used to produce Villanovan ceramics (Barone et al., 2010).

\section{Conclusions}

The results of this study provide new insights into the connections between Etruria and Sardinia during the early Villanovan period $\left(9^{\text {th }}\right.$ century $B C$, according to the traditional chronology), and they reflect a composite picture worthy of further exploration. The combination of petrographic and geochemical characterisation was especially effective in distinguishing between distinct traditions of pottery production represented in the Spalmatore di Terra assemblage. Eight petrographic groups were identified, and these include locally produced vessels from Sardinia as well as a variety of wares that can be traced to production centres in southern and northern Etruria. 
These results are significant in that they represent the first documented evidence of Villanovan ceramics in Sardinia, that also suggest a connection with both northern and southern Etruria. Considering the high degree of diversity in the assemblage - in combination with the lack of evidence for residential habitation and the inhospitable nature of Tavolara itself - we suggest that the island may have acted as a site for the exchange of goods. There are interesting similarities between Spalmatore di Terra and middle-Thyrrenian coastal sites of the Early Iron Age. These sites are marked by substantial accumulations of fragments of olle d'impasto rossiccio as well as possible pyrotechnological installations and storage pits, all of which suggest a link to productions activities connected to coastal environments. On Tavolara, the presence of Etrurian olle d'impasto rossiccio wares could be related to the storage and transport of food supplies necessary for boats engaged in transmarine crossings (di Gennaro 2019, 57).

There are still many open questions about the duration and frequency of interactions between Tavolara and Etruria that need to be addressed through continued archaeological investigations on the island. More comparative petrographic and geochemical data of Villanovan pottery from Etruria is also needed before more robust interpretations can be proffered. Regardless, what is certain is that this site cannot be interpreted as the sole means of trans-marine relations between Nuragic Sardinia and the Villanovan world in their complex variety and articulation.

Acknowledgments. We gratefully acknowledge the Soprintendenza per I Beni Archeologici per le Province di Sassari e Nuoro for assistance in obtaining permission to study the samples of this study. We would also like to thank Lars Heinze for the use of the pXRF instrument used in this analysis and for his help in editing several of the figures. Feedback and fruitful comments from Marcello Antonj, Francesco Carrera, Lionello Morandi, Pasquino Pallecchi, Stefano Segadelli and Giovanni Vezzoli were also very much appreciated. S.A. and C.B. would 
also like to acknowledge the Excellence Initiative of the Eberhard Karls Universität Tübingen and the Ministry for Science, Research, and Art of Baden-Württemberg for the generous support they provided to this research.

Author Contributions. Silvia Amicone: conceptualization, funding acquisition, investigation, methodology, project administration, petrographic analysis and statistical treatment of pXRF data, writing (original draft); Kyle Freund: investigation, methodology, pXRF analysis and statistical treatment of the data, writing (original draft); Paola Mancini: sampling, excavation, archaeological background, reviewing and editing the original draft; Rubens D'Oriano: sampling, excavation, archaeological background, reviewing and editing the original draft; Christoph Berthold: funding acquisition, methodology, reviewing and editing the original draft.

\section{References}

Alberti, A., Bertini, M., Del Bono, G.L., Nappi, G. and Salvati L., 1970. Note illustrative della carte geologica d'Italia: Tuscania (foglio 136) e Civitavecchia (foglio 142). Ercolano (Napoli), Poligrafica e Cartevalori.

Alessandri, L., Achino, K.F., Attema, P.A.J, de Novaes Nascimento, M., Gatta, M., Rolfo, M. F., Sevink, J., Sottili. G. and van Gorp, W., 2019. Salt or fish (or salted fish)? The Bronze Age specialised sites along the Tyrrhenian coast of Central Italy: New insights from Caprolace settlement. PLOS-ONE 14(11), 1-41.

Amicone, S., Croce, E., Castellano, L., and Vezzoli. G., 2020. Building Forcello. Etruscan wattle and daub techniques in the Po Plain (Bagnolo San Vito-Mantua, northern Italy). Archaeometry 62 (3), 521-537.

Aranguren, B., Cinquegrana, M.R., De Bonis, A., Guarino, V., Morra, V. and Pacciarelli, M., 2014. Le strutture e lo scarico di olle del Puntone Nuovo di Scarlino (GR) e i siti costieri specializzati della protostoria mediotirrenica. Rivista di Scienze Preistoriche 64, 227-258. 
Barone, G., Maria Belfiore C., Mazzoleni, P., Pezzino, A. and Viccaro, M., 2010. A volcanic inclusions based approach for provenance studies of archaeological ceramics: application to pottery from southern Italy. Journal of Archaeological Science 37, 713-726.

Bartoloni, G. and Delpino, F. 2005 (eds). Oriente e Occidente: metodi e discipline a confronto, riflessioni sulla cronologia dell'età del ferro in Italia, atti dell'Incontro di studi, Roma, 30-31 ottobre 2003. Pisa, Istituti Editoriali e Poligrafici Internazionali.

Borges, B., Tol, G., and de Haas, T. 2018. Reconstructing production technology and distribution, using thin section petrography: A pilot study of Roman pottery production in the Pontine Region, Central Italy. Journal of Archaeological Science: Reports 21, 1064-1072.

Camporeale, G., 2013. Artigiani e mercanti stranieri in Etruria ed Etruschi fuori d'Etruria in età villanoviana. Annali della Fondazione per il Museo Claudio Faina 20, $23-57$.

Carmignani, L. and Lazzarotto, A. 2004. Carta geologica della Toscana 1: 250,000. Regione Toscana.

Cohen, S., 2018. Finding a middle ground in the burial ground: Mortuary behaviour at Populonia and Vetulonia in the Early Iron Age. In E. Herring and E. O. Donoghue (eds), The Archaeology of Death. Proceedings of the Seventh Conference of Italian Archaeology held at the National University of Ireland, Galway, April 16-18, 2016. Oxford, Archaeopress, 181188.

Cygielman, M., Lo Schiavo, F., Milletti M., and Pagnini L., 2015. Populonia e Vetulonia fra Corsica e Sardegna. In: M. L. Haack (ed.) La Corsica e Populonia. Atti del XXVIII Convegno di Studi Etruschi ed Italici (Bastia-Aléria-Piombino-Populonia 2011). Roma, Presses Universitaires de France, 273-315.

Day, P., Kiriatzi, E., Tsolakidou A., and Kilikoglou, V., 1999. Group therapy in Crete: a comparison between analysis by NAA and thin section petrography of early Minoan pottery. Journal of Archaeological Science 26, 1025-1036. 
De Angelis, D., 2001. La ceramica decorata di stile "villanoviano" in Etruria meridionale. Soveria Mannelli. Rubbettino.

Delpino, F., 2002. Brocche a collo obliquo dall'area etrusca. In: O. Paoletti (ed.). Etruria e Sardegna centro-settentrionale tra l'età del bronzo finale e l'arcaismo. Atti del XXI Convegno di Studi Etruschi Italici (Sassari-Alghero-Oristano-Torralba 1998). Pisa-Roma, Istituti Editoriali e Poligrafici Internazionali, 364-385.

De Marco, C., 2017. Ipotesi interpretative dell'industria ceramica di Torre Mozza (Livorno), nell'ambito dei siti costieri medio-tirrenici dell'età del Bronzo in base ad analisi Archeometriche. In: Vannini (ed.), Florentia. Studi di Archeologia, vol. 3. Firenze, Firenze Unversity Press, 67-85.

di Gennaro, F., 2019. Uno stanziamento “etrusco" del X secolo a Tavolara. In S. Rafanelli (ed.) Alalia. La battaglia che ha cambiato la storia. Greci, Etruschi e Cartaginesi nel Mediterraneo del VI sec. a. C.. Vetulonia, ARA edizioni, 54--57.

di Gennaro, F., D’Oriano, R., Mancini, P., Amicone S. forthcoming. L'insediamento villanoviano dell'isola di Tavolara. Fasti Online.

Eckert, S.L., Schleher, K.L., \& James, W.D., 2015. Communities of identity, communities of practice: understanding Santa Fe Black-on-White pottery in the Española Basin of New Mexico. Journal of Archaeological Science 63, 1-12.

Force, E.R., 2015. Geologic aspects of ancient Villanovan settlement distributions in central Italy. Catena $125,162-168$.

Forte, V. and Medeghini, L., 2017. A preliminary study of ceramic pastes in the Copper Age pottery production of the Rome area. Archaeological and Anthropological Sciences 9, 209222.

Franzini, M. and Lezzerini, M., 1998. Le pietre dell'edilizia medievale pisana e lucchese (Toscana occidentale). 2. I calcari selciferi del Monte Pisano. Atti della Società Toscana di Scienze Naturali Residente in Pisa (Memorie. Serie A) 105, 1-8. 
Garzanti, E., Canclini, S., Moretti Foggia, F. and Petrella, N., 2002. Unraveling magmatic and orogenic provenance in modern sand: The back-arc side of the Apennine thrust belt, Italy. Journal of Sedimentary Research 72, 2-17.

Guidi, A., 1980. Studi sulla decorazione metopale nella ceramica villanoviana. Firenze, Olschki.

Helfert, M., Mecking, O., Lang, F. and von Kaenel, H.M., 2011. Neue Perspektiven für die Keramikanalytik. Zur Evaluation der portablen energiedispersiven

Röntgenfluoreszenzanalyse (P-ED-RFA) als neues Verfahren für die geochemische Analyse von Keramik in der Archäologie. Frankfurter elektronische Rundschau zur Altertumskunde $14,1-30$.

Hunt, A., and Speakman, R.J., 2015. Portable XRF analysis of archaeological sediments and ceramics. Journal of Archaeological Science 53, 626-638.

Iaia C. 2017. External relationship (Early Iron Age). In: A. Naso (ed.), Etruscology. Boston; Berlin, De Gruyter, 811-830.

Interdonato, C., 2013. Studi archeometrici su ceramica di impasto. Prospettive e primi risultati. In: P. A. Attema, F. di Gennaro and E. Jarva (eds), Crustumerium. Archaeology and Identity of a Latin Settlement near Rome. Groeningen, University of Groeningen/Groeningen Institute of Archaeology and Barkhuis, 117-125.

Kieft, D., Jamieson, N., Rout, B., Szymanski, R., and Jamieson, A.S., 2002. PIXE cluster analysis of ancient ceramics from North Syria. Nuclear Instruments and Methods in Physics Research B 190(1-4), 492-496.

Kristiansen, K., 1993. From Villanova to Seddin: the reconstruction of an elite exchange network during the eighth century BC. In: C. Scarre and F. Healy (eds), Trade and Exchange in Prehistoric Europe. Oxford, Oxbow Books, 143-154.

Levi, T., Cannavò, V. and Brunelli, D., 2019. Atlas of ceramic fabric 2. Italy: Southern Tyrrhenian Neolithic - Bronze Age. Oxford, Archaeopress. 
Lo Schiavo, F., 1978. Le fibule della Sardegna, Studi Etruschi 46, 25-46.

Lo Schiavo, F., 2005. Le brocchette askoidi nuragiche nel Mediterraneo all'alba della storia, Sicilia Archeologica 38(103), 101-116.

Lo Schiavo, F., and Milletti, M., 2014. The Nuragic heritage in Etruria. In J. MacIntosh Turfa, The Etruscan World. Oxon, Routledge, 264-278.

Lo Schiavo, F., Macnamara, E. and Vagnetti, L. 1985. Late Cypriot imports to Italy and their influence on local bronzework, Papers of the British School at Rome 53, 1-71.

Lo Schiavo, F., Falchi, P. and Milletti, M., 2013. Sardegna ed Etruria tirrenica: identità in formazione. Ripostigli e scambi della fase di transizione fra la fine del Bronzo Finale e la

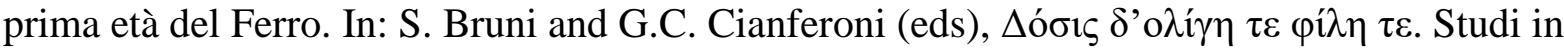
onore di Antonella Romualdi. Edizioni Polistampa, Firenze, 371-416.

Martini, F. Pallecchi, P. and L. Sarti, 1996. La ceramica preistorica in Toscana. Artigiani e materie prime dal Neolitico all'età del bronzo. Città di Castello, Garlatti e Razzai.

Milletti, M., 2012. Cimeli d'identità. Tra Etruria e Sardegna nella prima età del Ferro. Roma. Officina Etruscologia.

Morandi, L. F., Porta, S. N. and Ribechini, E., 2018. Evidence for birch bark tar use as an adhesive and decorative element in Early Iron Age central Italy: technological and socioeconomic implications. Archaeometry 60(5), 1077-1087.

Morandi, L.F., in press. La Collezione Guidi al Museo Archeologico di Grosseto. Reperti dalla necropoli villanoviana di Colle Baroncio e la prima età del Ferro a Vetulonia. Grosseto, Comune di Grosseto.

Muntoni, I. and Pallecchi, P. 2002. Composizione e provenienza delle materie prime utilizzate per la produzione vascolare. In: A. Manfredini (ed.) Le Dune, il lago, il mare. Una comunità di villaggio dell'età del Rame a Maccarese. Origines, Firenze, 102-115. 
Orton, C., and Hughes, M., 2013. Pottery in Archaeology. Cambridge, Cambridge Archaeology Press.

Ottomano, C., 2006. Analisi mineralogico-petrografica di tre campioni di ceramica. Mediterranea 3, 81-85.

Pacciarelli, M., 2000. Dal villaggio alla città. La svolta protourbana del 1000 a.C. nell'Italia tirrenica. Firenze, All'Insegna del Giglio.

Quinn, P.S., 2013. Ceramic Petrography. The Interpretation of Archaeological Pottery and Related Artefacts in Thin Section. Oxford, Archeopress.

Rossi, F., 2017. Duna Feniglia - Sede Forestale (sito TF01). Un sito produttivo villanoviano. In: N. Negroni Catacchio, M. Cardosa and A. Dolfini (eds), Paesaggi d'Acque. La Laguna di Orbetello e il Monte Argentario tra Preistoria ed Età Romana. Milano, Centro Studi di Preistoria e Archeologia, 230-251.

Salis, G. and Minoja, M. E., 2015. Un contributo al catalogo delle fibule rinvenute in Sardegna. Alcune considerazioni. Quaderni 26, 151-164.

Sayre, E.V., Dodson, R.W., and Thompson, D.B., 1957. Neutron activation study of Mediterranean potsherds. American Journal of Archaeology 61, 35-41.

Trojsi, G., 2012. Analisi archeometriche degli intonaci argillosi. Mediterranea 9, 255-258.

Toms, J. 1996, Symbolic expression in Iron Age Tarquinia: the case of the biconical urn. In C. Briese, K. Mansel and R. Docter (eds), Interactions in the Iron Age: Phoenicians, Greeks and the Indigenous Peoples of the Western Mediterranean. Die Akten des internationalen Kolloquiums in Amsterdam am 26. un 27. März 1992. Hamburger Beiträge 19/20, Hamburg, $139-161$.

Zucca, R., 2012. La Sardegna nuragica nel Mediterraneo tra la fine dell'età del Bronzo e gli inizi del Ferro. In: P. Bernardini and M. Perra (ed.). I Nuragici, i Fenici e gli altri: Sardegna e Mediterraneo tra bronzo finale e prima età del ferro. Atti del I Congresso internazionale in 
occasione del venticinquennale del Museo Genna Maria di Villanovaforru, 14-15 dicembre 2007. Sassari, C. Delfino, 209-220.

Whitbread, I.K., 1995. Greek Transport Amphorae: A Petrological and Archaeological Study. Athens: British School at Athens, Fitch Laboratory Occasional Paper, 4.

\section{Tables}

Table 1. List of Spalmatore di Terra samples selected for archaeometric analysis. Note that sample numbers are not consecutive because artefacts dating to other time periods were not included in this study.

Table 2. Detailed description of the petrographic results of samples from Spalmatore di Terra.

Table 3. Results from analyses of ceramic samples using pXRF instrumentation. Results for major elements are normalized to $100 \%$ in their oxide form, calculated by stoichiometry, while the trace elements are quantified in ppm. PG: Petrographic group. 